\title{
EFFECTS OF ROYAL JELLY ON ENERGY STATUS AND EXPRESSION OF APOPTOSIS AND BIOTRANSFORMATION GENES IN NORMAL FIBROBLAST AND COLON CANCER CELLS
}

\author{
Milena M. Jovanović ${ }^{1 *}$, Maja Đ. Ćupurdija ${ }^{1}$, Danijela D. Nikodijević1, \\ Milena G. Milutinović ${ }^{1}$, Danijela M. Cvetković ${ }^{1}$, Jelena D. Rakobradović ${ }^{2}$, \\ Snežana D. Marković \\ ${ }^{1}$ University of Kragujevac, Faculty of Science, Department of Biology and Ecology, \\ Radoja Domanovića 12, 34000 Kragujevac, Serbia \\ ${ }^{2}$ Institute for Oncology and Radiology of Serbia, 11000 Belgrade, Serbia \\ *Corresponding author; E-mail: jovanovic.milena28@gmail.com
}

(Received March 8, 2018; Accepted March 29, 2018)

\begin{abstract}
Royal jelly is natural bee product, traditionally used in medicine for antitumor, anti-inflammatory, antioxidant, antibiotic and many other beneficial properties. The aim of this study was to determine biological effects of royal jelly samples originating from Serbia on normal human fibroblast (MRC-5) and colorectal cancer (HCT-116 and SW-480) cells. MTT cell viability assay was used to determine cytotoxic activity, and NBT test was used for determination of superoxide anion radical concentration. Parameters of cell energy status were determined using LDH and ATP colorimetric methods. Relative expression of mRNA of apoptosis and biotransformation genes was monitored by qPCR method. Royal jelly affected cell viability, caused oxidative stress appearance and elevated parameters of energy status in cancer cell lines. The relative expression of genes whose proteins are included in biotransformation of xenobiotics were changed with notable suppression of CYPlAl, while increased expression of apoptosis genes was noted in tested cell lines. Royal jelly demonstrated cell selective effect and could be prospective in anticancer therapy.
\end{abstract}

Keywords: apoptosis, LDH, royal jelly, superoxide anion radical, ATP, colorectal cancer.

\section{INTRODUCTION}

Colorectal cancer is major public health problem and among the most commonly diagnosed type of cancer around the world, counting more than a million cases detected on an annual basis (NASRALLAH and EL-SIBAI, 2014). Apoptosis is programmed cell death, an essential genetically controlled process, which regulates tissue homeostasis and elimination of genetically damaged cells. Tumor progression is result of successful avoidance of apoptosis, where altered expression of genes included in apoptotic pathway contribute to inhibition of cell death and enhance cell proliferation. Bcl-2 protein family is responsible for regulation of apoptosis, consisting of pro- and anti-apoptotic proteins and therefore has been targeted for antitumor therapy (BAIG et al., 2016). This process is depended on energy (ELMORE, 2007). Modified energy status in cancer cells is characterized by elevated rate of aerobic glycolysis. 
Enzyme lactate dehydrogenase (LDH) catalyzes conversion of pyruvate to lactate, final step in anaerobic glycolysis, enabling generation of sufficient amount of energy (ATP molecules), required for increased proliferation of cancer cells, as well as apoptotic processes (VALVONA et al., 2016). Reactive oxygen species (ROS), such as superoxide anion, are generated during metabolic processes in cells. Mild ROS levels have significant impact on many cell processes including cell proliferation, activation of specific stress-induced signaling pathways, while accumulation of ROS can induce apoptotic pathway (LEE and KANG, 2013; KAMOGASHIRA et al., 2015; PAGES et al., 2015). Elevated ROS generation can also depend on genes and proteins included in biotransformation of xenobiotics (HRYCAY and BANDIERA, 2015). Mechanism of biotransformation of most drugs used in anticancer therapy depends on variety of enzymes expressed in cancer cells, such as cytochrome P450 (CYP family) 1A1, glutathione S-transferase P1 (GSTP1), multidrug resistance protein 2 (MRP-2). Genes that encode those proteins could be targeted in anticancer therapy (TAMASI et al., 2011; SODANI $e t$ al., 2012).

Considering the fact that cancer is multifactorial disease, dietary habits and nutrition quality are factors of significant influence in colorectal cancerogenesis (KAUR et al., 2009). Currently, major attention has been focused on natural products as part of daily diet intake, with a positive influence on reducing the risk of cancer (KARADENIZ et al., 2011; NABAS et al., 2014). Many studies have recently been oriented toward pharmacological properties of bee products, which are well known both in traditional and modern medicine (NAKAJIMA et al., 2009; PASUPULETI et al., 2017).

Royal jelly (RJ) is one of the most attractive natural products, secreted by the hypopharyngeal and mandibular glands of worker honeybees (Apis mellifera L.). It is a milky white secretion with a sharp smell and fruity taste, an essential food for both the queen bee and her larvae (SUZUKI et al., 2008; RAMADAN and AL-GHAMDI, 2012; SHIRZAD et al., 2013). Composition of RJ includes many important compounds such as proteins, lipids, essential amino acids, minerals, vitamins, sugars, nucleic acids, enzymes, hormones, phenols (SUZUKI et al., 2008; KARADENIZ et al., 2011; ORŠOLIĆ, 2013). Due to its complex composition, RJ has demonstrated various pharmacological activities: antitumor, anti-inflammatory, antioxidant, antibiotic, immunomodulatory, hypotensive, antihypercholesterolemic, hypoglycemic, antiallergic, antiaging, hepatoprotective, and many other (IZUTA et al., 2009; PAVEL et al., 2011; SUGIYAMA et al., 2012; SUPABPHOL and SUPABPHOL, 2013; MOFID et al., 2016).

According to our knowledge, no data regarding the effect of royal jelly originating from Serbia on ROS concentration, energy status, relative expression of apoptosis and biotransformation genes in cancer cell lines is available in the literature. The aim of this study was to characterize the biological activity of RJ in normal human fibroblast (MRC-5) and colorectal cancer (HCT-116 and SW-480) cells.

\section{MATERIALS AND METHODS}

\section{Chemicals}

Dulbecco's Modified Eagle Medium (DMEM) and Phosphate Buffered Saline (PBS) were obtained from GIPCO, Invitrogen, USA. Fetal Bovine Serum (FBS) and Trypsin EDTA was obtained from PAA (The Cell Culture Company, Pasching, Austria). Dimethyl Sulfoxide (DMSO), 3-[4,5-dimethylthiazol-2-yl]-2,5-diphenyltetrazolium bromide (MTT), Nitro Blue tetrazolium (NBT), Ethidium bromide (EB), PMS (N-methylphenazonium methyl sulfate), INT (2-p-iodophenyl-3-p-nitrophenyl-5-phenyl tetrazolium chloride), NAD (nicotinamide adenine dinucleotide) and chloroform were purchased from SERVA, Germany. Acridine Orange (AO) was obtained from Acros organics, USA. ATP assay kit and Triton X-100 were 
purchased from Sigma Aldrich, USA. TRIzol and molecular biology grade water were obtained from Ambion, USA. High-Capacity cDNA Reverse Transcription Kit Applied Biosystems were obtained from Termo Fisher Scientific, USA. SensiFAST SYBR Lo-ROX kit was from Bioline, UK. Primers used for relative expression of genes were from Eurofins Genomics, Ebersberg. All other used solvents and chemicals were of analytical grade.

\section{Royal jelly preparation}

Native RJ sample (originated from Apis mellifera L.) was produced by bee culture located in Velika Plana, Podunavlje District of Central Serbia, and collected in the spring of 2017. Fresh RJ was stored at $-20{ }^{\circ} \mathrm{C}$ until used. Prior to the analysis, RJ was defrosted and dissolved in PBS, and then diluted with the culture medium. The stock solution $(1 \mathrm{mg} / \mathrm{ml})$ was sterilized by filtropur S 0.2 for sterile filtration and diluted by medium to various working concentrations.

\section{Cell preparation and culturing}

Normal lung fibroblasts MRC-5 and colorectal cancer cell lines HCT-116 and SW480 (obtained from American Type Culture Collection) were maintained in DMEM supplemented with $10 \% \mathrm{FBS}, 100 \mathrm{units} / \mathrm{ml}$ penicillin and $100 \mu \mathrm{g} / \mathrm{ml}$ streptomycin. Cells were cultured in humidified atmosphere with $5 \% \mathrm{CO}_{2}$ at $37{ }^{\circ} \mathrm{C}$, grown in $75 \mathrm{~cm}^{2}$ cell culture flask until cell confluence at 70 to $80 \%$. After a few passages, cells were seeded for different assays.

\section{Cell viability assay (MTT assay)}

Cytotoxic effects of RJ were determined by MTT assay (MOSSMAN, 1983) and previously described in detail (ĆURČIĆ et al., 2012). MRC-5, HCT-116 and SW-480 cells were treated with various concentrations of RJ $(1,10,50,100,250$ and $500 \mu \mathrm{g} / \mathrm{ml})$ for 24 and $72 \mathrm{~h}$ of initial treatment.

\section{Fluorescence microscope analysis of cell death}

For the analysis of cell death, microscopic fluorescent assay Acridine orange/ethidium bromide (AO/EB) double staining was used (BASKIĆ et al., 2006) and previously described in detail (ĆURČIĆ et al., 2012). MRC-5, HCT-116 and SW-480 cells were seeded in a 96-well plate $\left(10^{4}\right.$ cells per well $)$ and after $24 \mathrm{~h}$ were treated with $100 \mu \mathrm{l}$ of $\mathrm{RJ}(250 \mu \mathrm{g} / \mathrm{ml})$ for 24 and $72 \mathrm{~h}$.

\section{Determination of Superoxide Anion Radical (NBT assay)}

The concentration of superoxide anion radical $\left(\mathrm{O}_{2}^{--}\right)$was determined by spectrophotometric method (AUCLAIR and VOISIN, 1985), previously described in detail (ŽIŽIĆ et al., 2013). Cells were seeded in 96-well plate $\left(10^{4}\right.$ cells per well) and treated with RJ $(10,100$ and $250 \mu \mathrm{g} / \mathrm{ml})$ for $24 \mathrm{~h}$.

\section{Evaluation of energy status parameters}

\section{Determination of lactate dehydrogenase concentration (LDH assay)}

The glycolysis intensity and cell damage were detected by spectrophotometric method - LDH assay (CHAN et al., 2013). Lactate dehydrogenase (LDH) is stable soluble enzyme present in almost all living cells. The principle of this colorimetric assay is based on activity 
of LDH, as glycolytic oxidoreductase, which catalyzes conversion of lactate to pyruvate and produces nicotinamide adenine dinucleotide (NADH). Diaphorase (PMS) is enzyme, which uses NADH to catalyze reduction of tetrazolium salt (INT) into colored formazan. The consumption of $\mathrm{NADH}$ is proportional to LDH activity and can be spectrophotometrically measured. Red formazan absorbs light at $490 \mathrm{~nm}$. Concentration of LDH was observed both in medium and in lysate.

MRC-5, HCT-116 and SW-480 cells were seeded in 6-well plate at a density of $1 \mathrm{x}$ $10^{5}$ cells per well in $1 \mathrm{ml}$ media. Cells were treated with $1 \mathrm{ml}$ of RJ $(100$ and $250 \mu \mathrm{g} / \mathrm{ml})$, for 24 and $48 \mathrm{~h}$. The untreated cells served as a control. Medium without cells was transferred from 6-well plate and centrifuged for $15 \mathrm{~min}$ at $1200 \mathrm{rpm}$ at $4{ }^{\circ} \mathrm{C}$. After that, $400 \mu \mathrm{l}$ of $9 \%$ Triton X-100 was added to lyse the cells in the lysis wells and mixed thoroughly using a pipette to make sure all cell membranes have degraded. Lysate was then centrifuged for 5 min at $1200 \mathrm{rpm}$ at $4{ }^{\circ} \mathrm{C}$. The supernatants $(50 \mu \mathrm{l})$ of both media and lysates were harvested and transferred to a 96-well plate. Prior to the assay, 2x LDH assay buffer (INT, PMS, NAD, lactic acid, $\mathrm{pH}$ 8.0) was made and $100 \mu \mathrm{l}$ of assay buffer was added to each of the assay wells. The assay plate was incubated for $30 \mathrm{~min}$ at room temperature in the dark. Absorbance was measured at $490 \mathrm{~nm}$ on Microplate Reader (ELISA RT-2100C).

\section{Measurement of adenosine triphosphate concentration (ATP assay)}

Measurement of intracellular ATP level was performed using colorimetric assay kit (Abcam, USA). Method is based on glycerol phosphorylation resulting in red colored reaction (CHEN et al., 2011). MRC-5, HCT-116 and SW-480 cells were seeded in T-25 $\mathrm{cm}^{2}$ cell culture flask $\left(10^{6}\right.$ cells per flask) and after $24 \mathrm{~h}$ of incubation were treated with $5 \mathrm{ml}$ of RJ (100 and $250 \mu \mathrm{g} / \mathrm{ml}$ ) for 24 and $48 \mathrm{~h}$. The untreated cells served as a control. After incubation with treatment, supernatant was rejected, and cells were lysed in $200 \mu \mathrm{l}$ of lysis buffer and mixed thoroughly using a pipette to make sure all cell membranes have degraded. Lysate was centrifuged for $2 \mathrm{~min}$ at $13000 \mathrm{rpm}$ at $4{ }^{\circ} \mathrm{C}$. $50 \mu \mathrm{l}$ of supernatant was added to a new 96-well plate and followed by the addition of $50 \mu \mathrm{l}$ of the Reaction Mix to each well with samples (work was performed on ice). After the incubation period in dark for $30 \mathrm{~min}$ at room temperature, the absorbance was measured at $570 \mathrm{~nm}$ using Microplate Reader (ELISA RT$2100 \mathrm{C})$. Concentration of ATP $(\mu \mathrm{mol} / \mu \mathrm{g})$ was calculated as:

$$
\text { ATP concentration }=\left(\frac{T s}{S v}\right) \times D
$$
same time

Ts = amount of ATP in sample well calculated from standard curve generated at the

$\mathrm{Sv}=$ sample volume added in the sample wells

$\mathrm{D}=$ sample dilution factor

\section{Apoptotic and biotransformation genes expression}

\section{Isolation of RNA from cultured cells}

RNA was isolated from normal fibroblast and colorectal cancer cells using protocol of CHOMCZYNSKI and SACCHI (1987). T-25 $\mathrm{cm}^{2}$ cell culture flasks were used to seed cells, and at confluency over $90 \%$ of cells were treated with RJ at concentration $100 \mu \mathrm{g} / \mathrm{ml}$, while the untreated cells served as control. After $24 \mathrm{~h}$ of treatment, cells were tripsinized and centrifuged at $1200 \mathrm{rpm}$ for $10 \mathrm{~min}$. Cells were resuspended in TRIzol at concentration of $10^{6}$ cells ${ }^{\prime} \mathrm{ml}$ of TRIzol. $200 \mu \mathrm{l}$ of chloroform was added to each sample, and after 15 seconds of mixing, samples were left for incubation 2-3 min at room temperature. After centrifugation of samples for $15 \mathrm{~min} / 12000 \mathrm{rpm}$ at $4{ }^{\circ} \mathrm{C}$ three visible phases were observed. The supernatant (containing RNA) was transferred to a new microtube, $500 \mu$ of isopropanol was added and 
RNA precipitated for $10 \mathrm{~min}$ at room temperature. Samples were centrifuged $10 \mathrm{~min} / 12000$ rpm at $4{ }^{\circ} \mathrm{C}$. Supernatant was removed and remaining residue washed with $1 \mathrm{ml}$ of $80 \%$ ethanol. After centrifuge $\left(5 \mathrm{~min} / 7500 \mathrm{rpm} / 4{ }^{\circ} \mathrm{C}\right)$ supernatant was removed and ethanol was left for air drying 2-3 min. RNA residue was resuspended in $20 \mu \mathrm{l}$ molecular biology grade water, and then incubated at $55{ }^{\circ} \mathrm{C}$ at thermoblock for 2-3 min. RNA concentration was measured in every sample using biophotometer (Eppendorf BioPhotometer Plus). Indicator of RNA purity was considered relation between absorbance in the range of 1.8 up to 2.0. Samples were aliquoted and preserved at $-80{ }^{\circ} \mathrm{C}$ until further use.

\section{Reverse transcription (RT-PCR)}

Translation of mRNA into a complementary DNA (cDNA) was performed using reverse transcriptase enzyme (BUSTIN, 2000). Commercially available kit High-Capacity cDNA Reverse Transcription Kit (Applied Biosystems) was applied, consisting of $2 \mu 110 \mathrm{x}$ Buffer RT, $2 \mu \mathrm{l}$ dNTP (concentration $5 \mathrm{mM}$ ), $2 \mu$ l oligo-dT primers, $11 \mu \mathrm{l}$ molecular biology grade water, $1 \mu \mathrm{l}$ Reverse Transcriptase (Sensiscript Reverse Transcriptase). $2 \mu 1$ of RNA sample (concentration $1 \mu \mathrm{g} / \mu \mathrm{l}$ ) was added to Master Mix. Eppendorf Mastercycler-PCR was programed and adapted according to manufacturer's instructions. The resulting cDNA was stored at $-80{ }^{\circ} \mathrm{C}$ until further use.

\section{Quantitative polymerase chain reaction ( $(\mathrm{PCCR})$}

Resulting cDNA was used to evaluate relative gene expression (ZHAI et al., 2005), applying commercially available kit (sensiFAST SYBR LO-Rox kit, Bioline). Kit components were vortexed before use and reaction mixture was made for each target gene separately adding forward/reverse primer mix $(0.5 \mu \mathrm{l}$ Forward primer and $0.5 \mu$ l Reverse primer, concentration $10 \mu \mathrm{M}) 10 \mu \mathrm{l}$ qPCR Master Mix. Reaction mixture was poured into a PCR assay plate and $2 \mu \mathrm{l}$ of cDNA sample was added and $7 \mu \mathrm{l}$ water molecular biology grade. Each qPCR cycle started with polymerase activation step $\left(95^{\circ} \mathrm{C} / 2 \mathrm{~min}\right)$, which was followed by 40 cycles repeating, each of them consisting of three steps: 1) denaturation of DNA at 95 ${ }^{\circ} \mathrm{C} / 5 \mathrm{sec}$; 2) primer hybridization (annealing) at $60{ }^{\circ} \mathrm{C} / 10 \mathrm{sec}$; 3) extension at $72{ }^{\circ} \mathrm{C} / 20 \mathrm{sec}$. After amplification was done, the result evaluation was made using Applied Biosystems 7500/7500 Real-Time PCR software. $\beta$-actin gene was selected as internal control gene for the experiment (SCHIMITTGEN and LIVAK, 2008). Calculation of relative gene expression in examined cells was performed by using following formula:

$$
\mathbf{2}^{-\Delta \Delta \mathrm{CT}_{\mathrm{T}}}=\Delta \boldsymbol{C}_{\mathrm{T}_{1}}-\Delta \mathrm{C}_{\mathrm{T}_{2}}
$$

$\Delta \boldsymbol{C}_{\mathrm{T} 1}=$ difference between $\mathrm{CT}$ values of examined gene in sample and CT values of $\beta$ actin in the sample;

$\Delta \mathbf{C} 2=$ difference between $\mathrm{CT}$ values of examined gene in control cells and CT values of $\beta$-actin in control cells.

Forward and Reverse primer sequences used in experiments were:

\begin{tabular}{|c|c|c|}
\hline Genes & Forward sequence & Reverse sequence \\
\hline$\beta$-actin & 5'-AAGCAGGAGTATGACGAGTCCG-3' & 5'-GCCTTCATACATCTCAAGTTGG-3' \\
\hline$B A X$ & 5'-GGACGAACTGGACAGTAACATGG-3' & 5'-GCAAAGTAGAAAAGGGCGACAAC-3' \\
\hline$B C L-2$ & 5'-CTACGAGTGGGATGCGGGAGATG-3' & 5'-GGTTCAGGTACTCAGTCATCCACAG--3' \\
\hline CYP1A1 & 5'-GCCCACAGCCCAGATAGCAA-3' & 5'-GGTCTGGCCAGGTCTAGGCA-3' \\
\hline GSTP1 & 5'-TCAAAGCCTCCTGCCTATAC -3' & 5'-AGGTGACGCAGGATGGTATT -3 \\
\hline$M R P-2$ & 5'-АТАССААТССАAGCСТСТАС-3, & 5'-GAATTGTCACCCTGTAAGAG-3' \\
\hline
\end{tabular}




\section{Statistical analysis}

The data are expressed as mean \pm standard error (SE). Statistical significance was determined using the Student's t-test or the one-way ANOVA test for multiple comparisons. A $\mathrm{p}$ value $<0.05$ was considered significant. The magnitude of correlation between variables was done using a SPSS (Chicago, IL) statistical software package (SPSS for Windows, ver.17, 2008). The $\mathrm{IC}_{50}$ values were calculated from the dose curves by a computer program (CalcuSyn).

The results for NBT, LDH and ATP assays were presented in relation to the number of viable cells on the basis data given in MTT test.

\section{RESULTS}

\section{Cytotoxic effects}

Evaluation of RJ effects on MRC-5, HCT-116 and SW-480 cell viability was determined by MTT assay. Based on the results, RJ showed no significant cytotoxic effect on all tested cell lines. Increased cell viability is evident after $24 \mathrm{~h}$ of treatment, and proliferative effect induced by RJ in lower concentrations in all three tested cell lines (Fig. 1). Higher RJ concentrations induced decrease in cell viability in all tested cell lines, but in cancer cells their recovery is noticeable. Slight cytotoxic effect of RJ was evident in tested cancer cell lines at $250 \mu \mathrm{g} / \mathrm{ml}$ concentration. Cancer cells exerted slightly higher sensitivity to the treatment than normal fibroblast cells.

The effect of RJ was expressed by $\mathrm{IC}_{50}$ values (inhibitory dose that inhibit cell growth by $50 \%$ ), used as a parameter for cytotoxicity, was higher than $500 \mu \mathrm{g} / \mathrm{ml}$. Considering weak antiproliferative effects, $\mathrm{IC}_{50}$ values are higher than the highest applied $\mathrm{RJ}$ concentration and could not be calculated. Per these criteria, RJ showed no cytotoxic effect on investigated cell lines. 


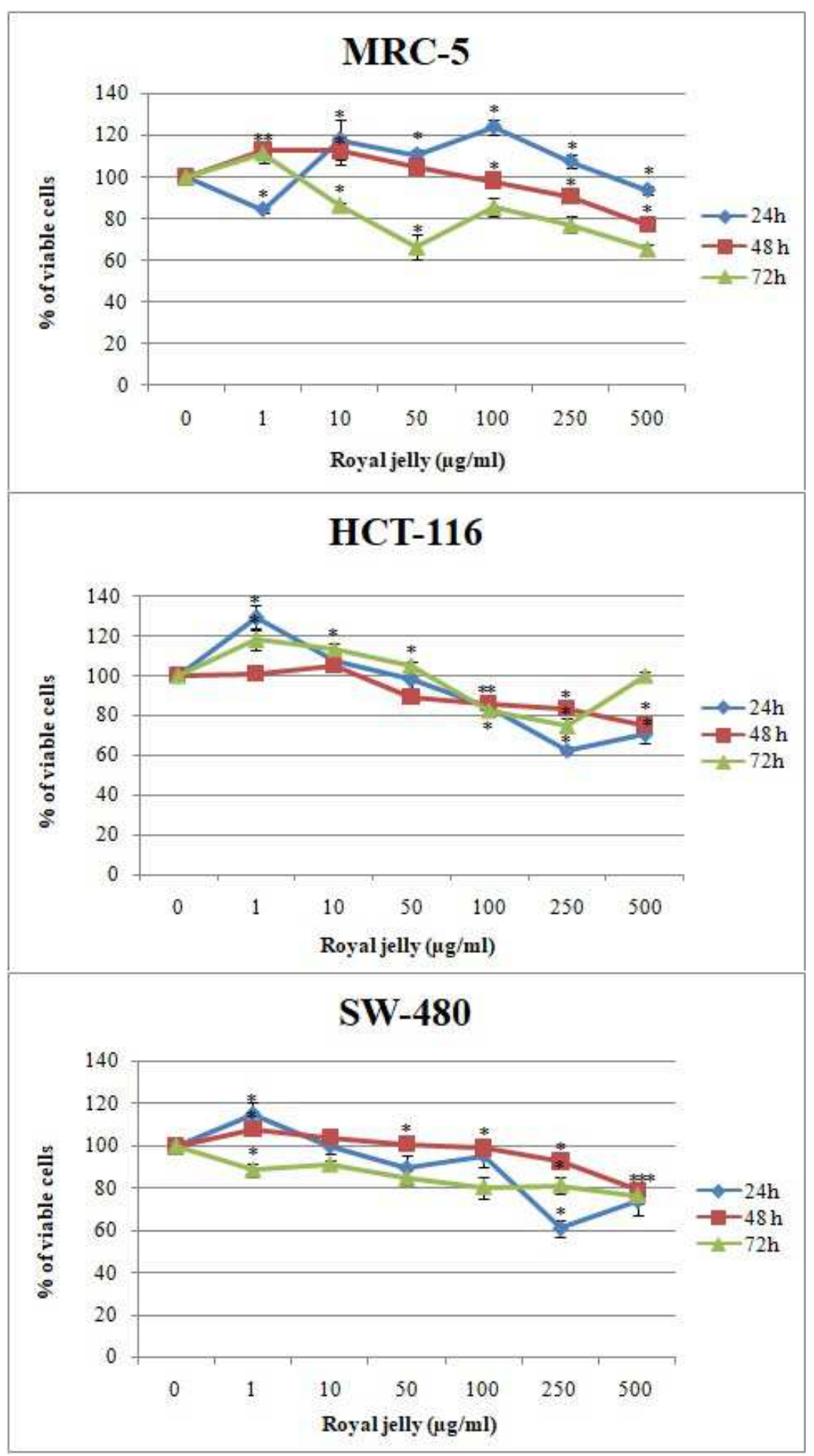

Figure 1. Effects of RJ on MRC-5, HCT-116 and SW-480 cell viability. Results are presented as means \pm SE of 3 independent experiments. *statistically significant difference $(\mathrm{p}<0.05)$ compared to control.

\section{Fluorescence microscope analysis of cell death}

In order to determine whether the inhibition of cell proliferation by RJ was due to the induction of apoptosis, AO/EB staining was performed. Cells were treated with RJ (250 $\mu \mathrm{g} / \mathrm{ml}$, concentration that induced slight cytotoxic effect in all tested cell lines) for 24 and 72 $\mathrm{h}$, while untreated cells served as control. Table 1 presents the percentage of viable cells, cells 
in early apoptosis, late apoptosis and necrosis MRC-5, HCT-116 and SW-480 cells after examined treatment. The RJ treatment did not cause significant visible morphological changes in investigated cell lines. RJ treatment mainly induced slight apoptosis (predominantly early apoptosis), while late apoptotic cells were absent, and low percentages of necrotic cells were observed. Generally, percentage of apoptosis (mainly early apoptosis) and necrosis was very low after applied treatment. Apoptosis occurred in control cells $72 \mathrm{~h}$ after RJ treatment was due to proliferation, outgrowing of cells and lack of nutrients, thus cell death.

Table 1. Effect of RJ on apoptosis in MRC-5, HCT-116 and SW-480 cells, stained with AO/EB.

\begin{tabular}{|c|c|c|c|c|}
\hline $24 \mathrm{~h}$ & $\begin{array}{c}\text { Viable cells } \\
(\%)\end{array}$ & $\begin{array}{c}\text { Early apoptotic } \\
\text { cells }(\%)\end{array}$ & $\begin{array}{l}\text { Late apoptotic } \\
\text { cells }(\%)\end{array}$ & $\begin{array}{c}\text { Necrosis cells } \\
(\%)\end{array}$ \\
\hline \multicolumn{5}{|l|}{ MRC-5 } \\
\hline Control & $100.00 \pm 0.01$ & I & I & l \\
\hline Treatment & $98.55 \pm 0.14 *$ & $1.46 \pm 0.14 *$ & I & I \\
\hline \multicolumn{5}{|l|}{ НCT-116 } \\
\hline Control & $99.06 \pm 0.29$ & $0.94 \pm 0.29 *$ & I & I \\
\hline Treatment & $97.70 \pm 0.17 *$ & $2.02 \pm 0.19 *$ & l & $0.29 \pm 0.02 *$ \\
\hline \multicolumn{5}{|l|}{ SW-480 } \\
\hline Control & $98.65 \pm 0.24 *$ & $0.90 \pm 0.06 *$ & $0.30 \pm 0.02 *$ & I \\
\hline Treatment & $97.47 \pm 0.10 *$ & $2.25 \pm 0.12 *$ & / & $0.28 \pm 0.02 *$ \\
\hline \multicolumn{5}{|l|}{$72 \mathrm{~h}$} \\
\hline \multicolumn{5}{|l|}{ MRC-5 } \\
\hline Control & $98.43 \pm 0.16 *$ & $1.15 \pm 0.30 *$ & I & $0.43 \pm 0.14 *$ \\
\hline Treatment & $97.64 \pm 0.22 *$ & $2.06 \pm 0.23 *$ & I & $0.30 \pm 0.01 *$ \\
\hline \multicolumn{5}{|l|}{ HCT-116 } \\
\hline Control & $96.67 \pm 1.14 *$ & $3.05 \pm 1.14 *$ & I & $0.29 \pm 0.02 *$ \\
\hline Treatment & $96.57 \pm 0.94 *$ & $2.88 \pm 0.63 *$ & I & $0.56 \pm 0.31 *$ \\
\hline \multicolumn{5}{|l|}{ SW-480 } \\
\hline Control & $97.97 \pm 0.02 *$ & $1.59 \pm 0.13 *$ & I & $0.44 \pm 0.15 *$ \\
\hline Treatment & $97.54 \pm 0.32 *$ & $1.89 \pm 0.06 *$ & I & $0.57 \pm 0.26 *$ \\
\hline
\end{tabular}

Results are presented as means $\pm \mathrm{SE}$ of 3 independent experiments.

*statistically significant difference $(\mathrm{p}<0.05)$ compared to control

\section{Concentration of Superoxide Anion Radical $\left(\mathrm{O}_{2}{ }^{-*}\right)$}

Assessment of RJ effects on $\mathrm{O}_{2}{ }^{--}$concentration in MRC-5, HCT-116 and SW-480 cells was determined by NBT assay and results are presented in Figure 2. Concentration of $\mathrm{O}_{2}{ }^{-}$in MRC-5 cells was lower compared to control cells, $24 \mathrm{~h}$ of treatment, but increase of $\mathrm{O}_{2}{ }^{-}$ production was detected after 48 and $72 \mathrm{~h}$ of treatment. RJ treatment generally increased concentration of $\mathrm{O}_{2}{ }^{-}$in tested cancer lines. Dose dependent increase in $\mathrm{O}_{2}{ }^{--}$production in HCT-116 cell line was observed after 24 and $48 \mathrm{~h}$ of treatment, while the highest statistically significant increase of $\mathrm{O}_{2} \cdot-$ concentration was noticeable $72 \mathrm{~h}$ after treatment. SW-480 cell line expressed slight increase in $\mathrm{O}_{2}{ }^{-}$concentration at $\mathrm{RJ}$ concentration of $10 \mu \mathrm{g} / \mathrm{ml}$, compared to control, while the highest increase was expressed at concentration $250 \mu \mathrm{g} / \mathrm{ml}$. Cancer cell line exhibited more evident sensitivity to the treatment regarding changes in $\mathrm{O}_{2}{ }^{-}$concentrations compared to normal fibroblast cells. 


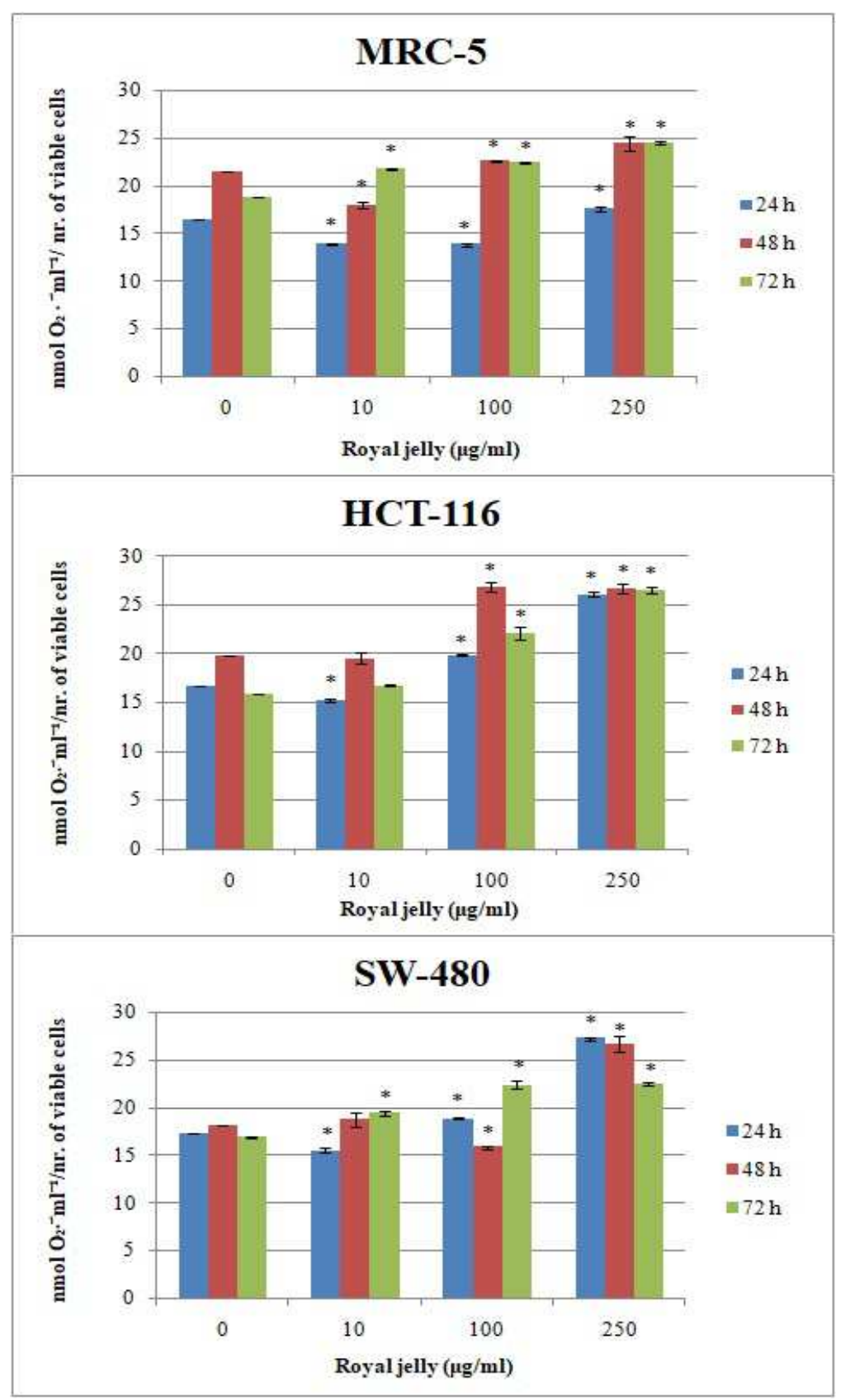

Figure 2. Effects of $\mathrm{RJ}$ on $\mathrm{O}_{2}-$ concentration ( $\mathrm{nmol} / \mathrm{ml}$ in relation to number of viable cells) in MRC-5, HCT-116 and SW-480 cell lines Results are presented as means \pm SE of 3 independent experiments.

*statistically significant difference $(\mathrm{p}<0.05)$ compared to control.

\section{Evaluation of energy status parameters}

\section{Lactate dehydrogenase concentration}

The basal LDH concentration in medium as well in lysate was similar both in normal fibroblast and cancer cells (Figs. 3 and 4) indicating equal rate of glycolysis.

RJ decreased LDH level in medium of MRC-5 cells after both 24 and $48 \mathrm{~h}$, while this parameter changed in cancer cells. Namely, LDH concentration slightly increased in HCT116 cells in dose-dependent manner after 24 and $48 \mathrm{~h}$ of treatment, which suggests to the eventual necrosis of cells. In SW-480 cells increased LDH level was expressed at RJ concentration $250 \mu \mathrm{g} / \mathrm{ml}$ after $24 \mathrm{~h}$. Our results showed weaker changes in LDH concentration in medium after $48 \mathrm{~h}$ of treatment (Fig. 3). 
LDH concentration in lysate of MRC-5 cells remained similar to the basal concentration. In cancer cells, increase of LDH level was significant and more pronounced after $24 \mathrm{~h}$ of treatment (Fig. 4). Cell selectivity of RJ treatment was prominent, apparently, HCT-116 cells exerted higher sensitivity to treatment than MRC-5 and SW-480 cells. Significant increase of this parameter in lysate of cancer cells, compared to normal fibroblast cells, indicate higher glycolysis intensity.

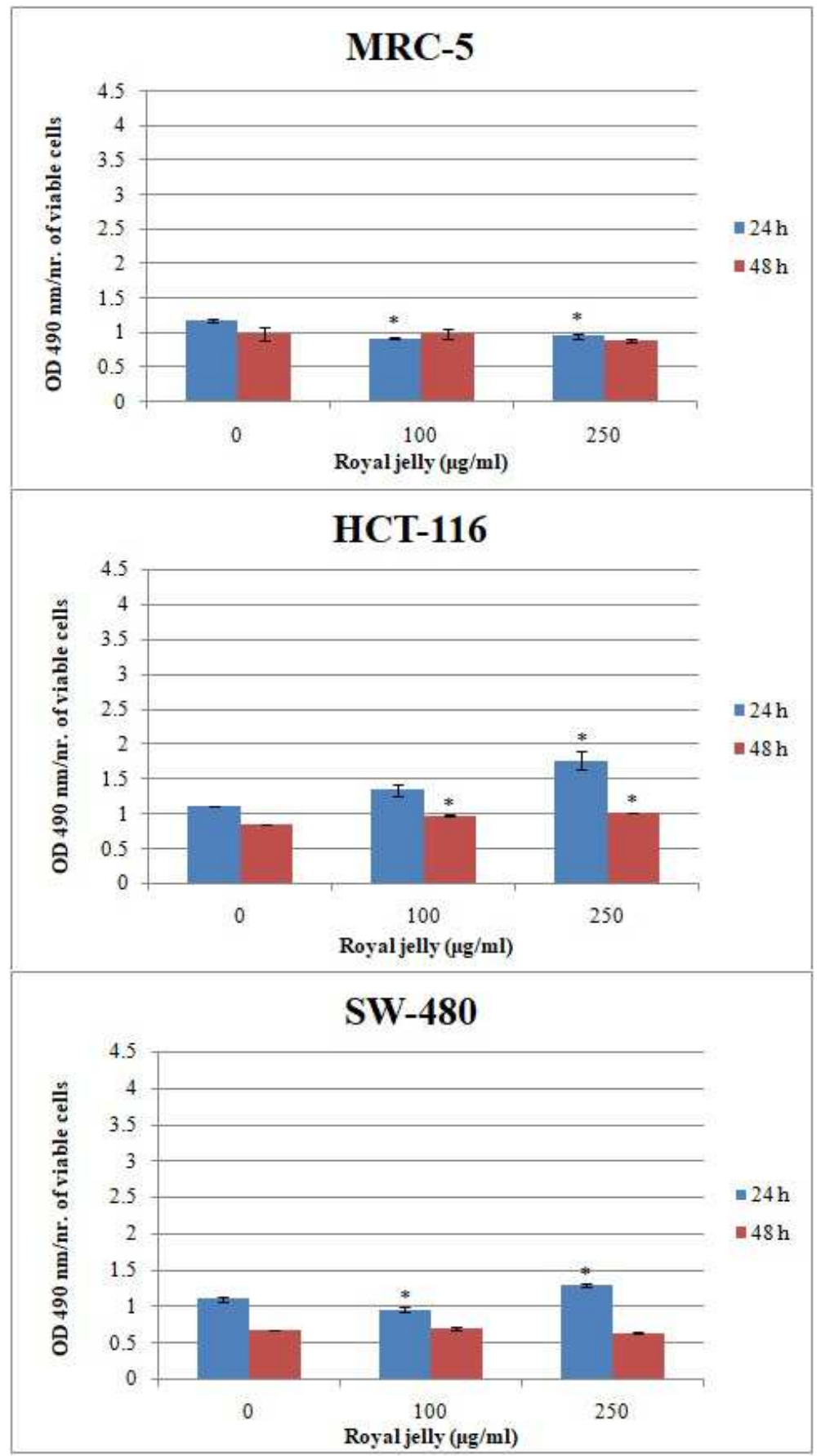

Figure 3. Effects of RJ on LDH concentration (OD $490 \mathrm{~nm}$ in relation to number of viable cells) in medium of MRC-5, HCT-116 and SW-480 cell lines.

Results are expressed as means \pm SE for 3 independent determinations. *statistically significant difference $(p<0.05)$ compared to control. 


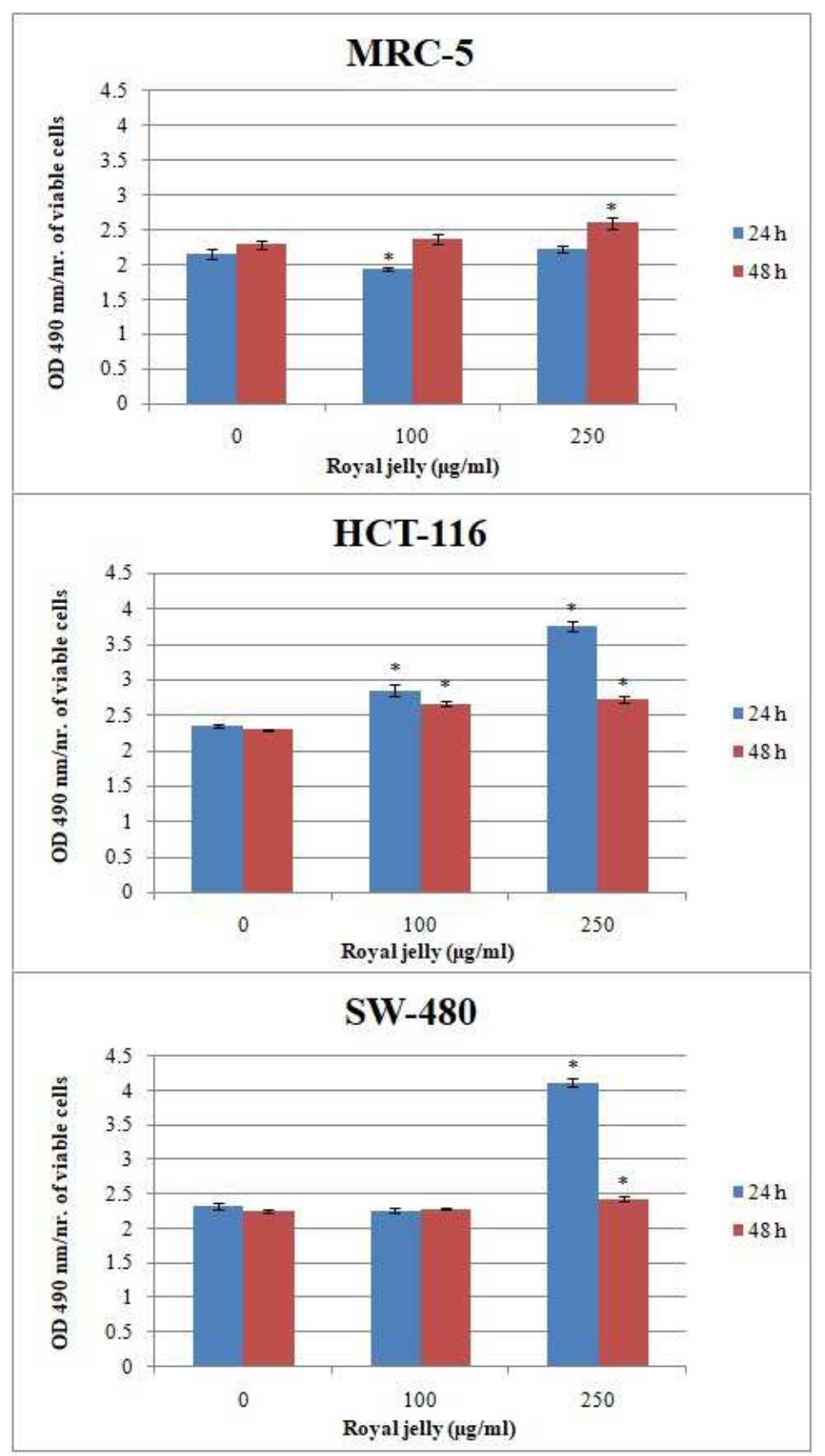

Figure 4. Effects of RJ on LDH concentration (OD $490 \mathrm{~nm}$ in relation to number of viable cells) in lysate of MRC-5, HCT-116 and SW-480 cell lines.

Results are expressed as means \pm SE for 3 independent determinations. *statistically significant difference $(\mathrm{p}<0.05)$ compared to control.

\section{The adenosine triphosphate concentration}

ATP concentration was measured in normal fibroblast MRC-5 and HCT-116 and SW480 cancer cell lines by performing ATP colorimetric assay. In MRC- 5 cells increase of this parameter was obvious after $24 \mathrm{~h}$ of treatment at concentration of $100 \mu \mathrm{g} / \mathrm{ml}$ of RJ, while at higher concentration the ATP level was decreased (Fig. 5). RJ induced decrease of ATP levels in MRC-5 cells at both applied concentrations $(100$ and $250 \mu \mathrm{g} / \mathrm{ml})$ after $48 \mathrm{~h}$ of treatment. After both treatment incubation periods, ATP concentration was significantly increased in 
cancer cell lines, indicating cell selective effect of RJ treatment. After $24 \mathrm{~h}$ of treatment, increase of ATP concentrations in cancer cells was prominent in dose-dependent manner, compared to the control. Increase of ATP level cells in dose-dependent manner was evident in HCT-116 after $48 \mathrm{~h}$ of treatment, while in SW-480 cells lower RJ concentration $(100 \mu \mathrm{g} / \mathrm{ml})$ induced increase in ATP, while the higher RJ concentration $(250 \mu \mathrm{g} / \mathrm{ml})$ induced decrease of ATP level (Fig. 5).

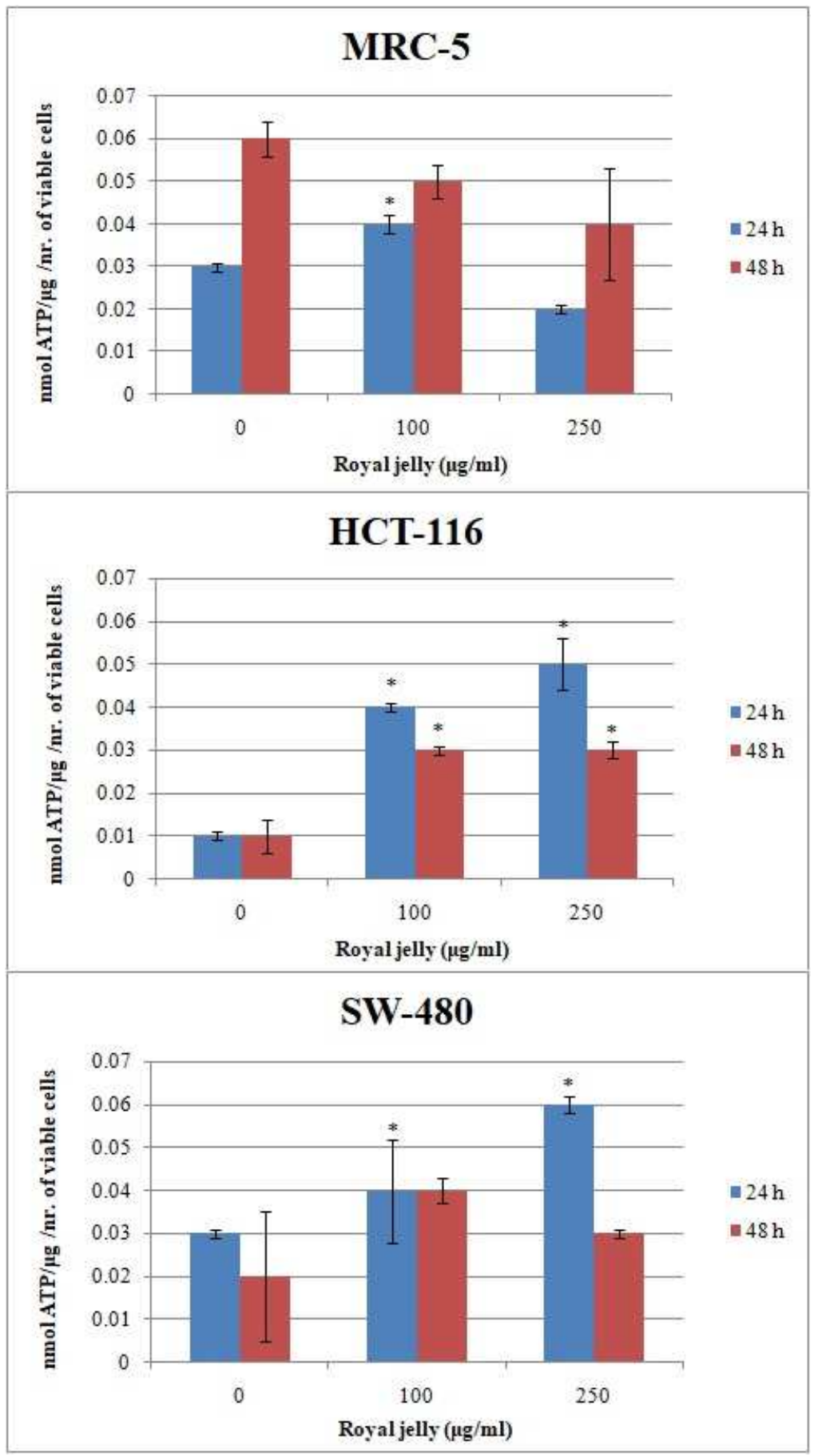

Figure 5. Effects of RJ on ATP concentration ( $\mathrm{nmol} / \mu \mathrm{g}$ in relation to number of viable cells) in MRC-5, HCT-116 and SW-480 cell lines.

Results are expressed as means \pm SE for 2 independent determinations. *statistically significant difference $(\mathrm{p}<0.05)$ compared to control. 


\section{Relative gene expression}

The expression of genes whose protein products were included in apoptosis $(B A X$, $B C L-2)$ and biotransformation of xenobiotics (CYP1A1, GSTP1, MRP-2) were monitored by qPCR method. The relative expression of target genes was calculated in relation of $\beta$-actin as housekeeping gene (endogenous control). Results presented as relative expression of target genes in treated cells in relation of control (untreated) cells (1) showed changes in genes expression in all tested cell lines after RJ treatment (Fig. 6). RJ treatment affected expression of apoptotic genes in all tested cell lines by increasing $B A X$ and $B C L-2$. RJ showed cell selective effect in this case, namely, more pronounced, higher expression was observed in normal fibroblast than in cancer cells. Inhibition of CYPIAl gene expression is evident in normal as well as in cancer cells. RJ increased expression of GSTP1 gene in MRC-5 and SW480, while the opposite effect was observed in HCT-116 cells. The increase of MRP-2 gene was evident in all tested cell lines after RJ treatment.

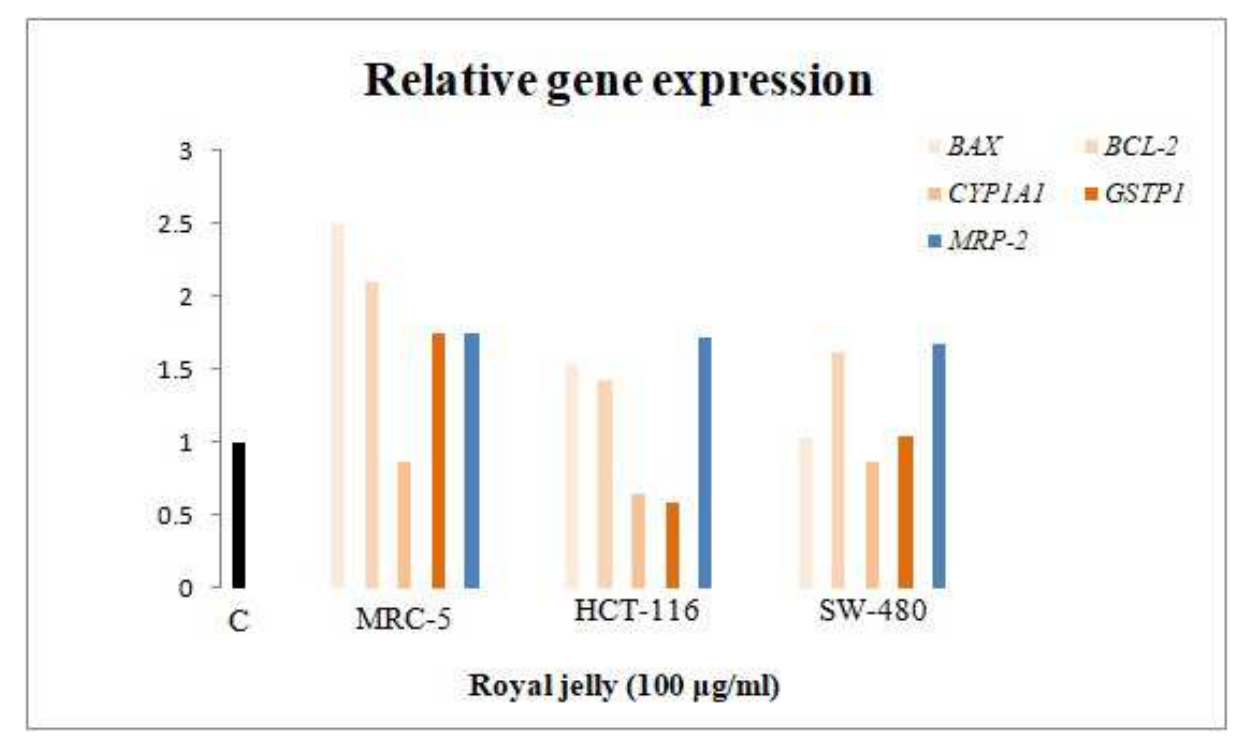

Figure 6. Effects of RJ on relative expression of $B A X, B C L-2, C Y P 1 A 1$, GSTP1, MRP-2 genes in MRC-5, HCT-116 and SW-480 cell lines.

\section{DISCUSSION}

The effects of RJ on cell proliferation have been previously reported, but there are no studies on HCT-116 and SW-480 cancer cells. In recent studies performed by FILIPIČ et al. (2015) the relatively low antiproliferative activity of $\mathrm{RJ}$ on $\mathrm{CaCo} 2$ colorectal adenocarcinoma cells, was noticed. Antiproliferative effect of RJ was suggested to be due to its protein fraction (major royal jelly proteins - MRJP), which prevented proliferation of MCF-7 human breast cancer cells induced by bisphenol $\mathrm{A}$ and decreased HeLa cells population by $50 \%$ (RAMADAN and AL-GHAMDI, 2012; FILIPIČ et al., 2015). On the contrary, lipid estrogenic component present in RJ increased proliferation of MCF-7 cells (PAVEL et al., 2011). RJ protein fraction also showed stimulative effect on human monocytes (FILIPIČ et al., 2015) and rat hepatocytes, suggesting that MRJP in RJ probably functions as growth factor (TORRESAcOSTA et al., 2015). According to our results, RJ applied in low concentrations stimulated cell proliferation of tested cell lines, while concentration $250 \mu \mathrm{g} / \mathrm{ml}$ exhibited weak cytotoxic effect in cancer cell lines. Cell selective effect of RJ treatment can be noticed since cancer cells show slightly more sensitive response of cancer cells to the treatment than normal fibroblast cells. In order to determine type of cell death at this concentration, we performed 
$\mathrm{AO} / \mathrm{EB}$ staining and concluded that cytotoxicity was due apoptosis. Investigated treatment did not induce necrosis. Also, level of LDH in cell culture medium, as indicator of necrosis, was relatively low compared to control, in tested cell lines, 24 and $48 \mathrm{~h}$ after RJ treatment, indicating that $\mathrm{RJ}$ did not induce necrosis.

Phenolic compounds are shown to induce pro-oxidant effect in cancer cells causing increased ROS production (ĆURČIĆ et al., 2014). Antioxidative properties of RJ are well known and attributed to polyphenols, flavonoids (flavonoles, flavanones, flavones) and cinnamic acid derivates present in RJ (RAMADAN and AL-GHAMDI, 2012). In our study, prooxidant effect occurred in cancer cells could be due to polyphenolics present in RJ. These compounds affect cancer cells targeting different signaling pathways such as cell proliferation and modulation of redox status (ZHOU et al., 2016). Changes in mitochondrial membrane permeability caused by increased levels of ROS are resulting in cytochrome c release and inducing apoptosis pathway (ĆURČIĆ et al., 2014). Our study showed elevated ROS production in cancer cells comparing to normal fibroblast MRC-5 and control values, especially concentration of $250 \mu \mathrm{g} / \mathrm{ml}$. This may suggest that slight cytotoxic effects in cancer cells could be result of oxidative stress caused by RJ treatment.

Apoptosis is process highly regulated by members of BCL-2 protein family, categorized into anti-apoptotic and pro-apoptotic proteins (BAIG et al., 2016). We assessed expression of anti-apoptotic $B C L-2$ and pro-apoptotic $B A X$ genes after exposure to RJ. Treatment induced notable higher expression of both genes in MRC-5 cells than in cancer cells. The treatment induced changes in expression of both genes in HCT-116 cells, with higher obtained values of pro-apoptotic $B A X$ gene expression, which is consistent with stronger cytotoxicity of RJ treatment in this cell line. Expression of anti-apoptotic $B C L-2$ gene was higher in SW-480 cells compared to pro-apoptotic $B A X$, which is in correlation with unchanged values of cell viability at RJ concentration of $100 \mu \mathrm{g} / \mathrm{ml}$.

Certain metabolites, especially fatty acids and nucleic acids are prerequisite in tumor cell for growth and proliferation under low oxygen levels. Overexpression of transcription factor like $H I F-1 \alpha$ in hypoxic conditions, which regulates expression of $\mathrm{LDH}$, leads to increased levels of LDH in cancer. However, it was observed that estrogen can also influence the expression of LDH (MIAO et al., 2013). It was reported previously that RJ exhibits estrogenic activity in vitro, through binding to estrogen receptor $\beta$ (ER $\beta$ ). This signaling pathway resulted in transcription modulation via estrogen response element (ERE) in DNA, as well as proliferation of tumor cells (SUZUKI et al., 2008). Our study showed that basal LDH concentration in lysate was similar in normal fibroblast and cancer cells, indicating equal rate of glycolysis. Cell selective effect of RJ was noted, by increasing levels of LDH in cancer cell lysate, while this parameter remained similar in normal fibroblast cells. Elevated LDH content in cancer cell lysate indicates hypoxic conditions and increased rate of glycolysis. Increased LDH concentration leads to higher activity of this enzyme and higher production of ATP, which is in accordance to our results. Elevated energy metabolism insures greater ATP production, needed for cell proliferation, as well as for apoptosis, energy-dependent cascade of molecular events (ELMORE, 2007). ATP as source of energy is needed for many metabolic processes in the cell, including biotransformation of xenobiotics (CROOM, 2012).

Our study revealed that RJ affected expression of biotransformation genes in normal fibroblast and cancer cells. Important enzyme included in metabolism of xenobiotics and oxygenation of organic substrates by reducing of molecular oxygen is cytochrome P450 CYP1A1, one of three members of CYP1 family (TAMASI et al., 2011; HRYCAY and BANDIERA, 2015). ROS can be generated as byproduct of molecular oxygen reduction process catalyzed by CYP enzymes as a consequence of control loss of this process (HRYCAY and BANDIERA, 2015). Expression of CYP1A1 is often altered in cancer, resulting in maintenance of drug resistance (TAMASI et al., 2011). Therefore, by suppressing the expression of 
CYP1A1, drug resistance in cancer could be reduced. According to our results, RJ treatment suppressed CYP1A1 expression in cancer cells compared to control values.

Another important enzyme with vital role in detoxification and metabolism of xenobiotics, including anticancer agents is glutathione S-transferase P1 (GSTP1), protein product of GSTP1 gene. GSTP1 catalyze addition of glutathione (GSH) to xenobiotics or metabolites of oxidative stress, thus neutralizing them. Trans-membrane MRPs are removing glutathione conjugates from the cell (NISSAR et al., 2017). We showed in our study that RJ treatment suppressed CYP1A and GSTP1 in HCT-116 cells. This ability of RJ to suppress expression of genes or activity of their protein products with important role in metabolism of cytostatics, could be very perspective in effectiveness of anticancer drugs applied in combination with RJ. Increased GSTPI and MRP-2 expression is expected in normal fibroblasts and other healthy cells, due their role in detoxification. This mechanism protects normal cells from xenobiotics, including any exogenous substances (PAJAUD et al., 2012).

MRP-2 protein is the major trans-membrane efflux transporter, member of MRP subfamily of ABC transporters, with role in ATP-dependent excretion of glutathione conjugates and other endogenous and xenobiotic compounds. According to previous reports, $M R P-2$ is expressed in cancer tissues, such as colorectal cancer, thus multidrug resistance of cancer cells depends on MRP-2 expression level (SODANI et al., 2012). In our study, increased expression of MRP-2 as a result of RJ treatment can be observed in all tested cell lines. RJ treatment, although non-toxic at applied concentration $(100 \mu \mathrm{g} / \mathrm{ml})$, was obviously recognized as xenobiotic by tested cells and thus possibly excreted from cells. Overexpression of $M R P-2$ requires ATP, which explains increasing of ATP concentration in treated cells.

\section{CONCLUSION}

Royal jelly originating from Serbia stimulates cells proliferation of all examined cell lines; however, at higher applied concentrations cytotoxic effects were evident in cancer cell lines. These cytotoxic effects were caused mainly by apoptosis, without necrotic effects, which was confirmed by LDH concentration in cell culture medium. The parameters of energy status were clearly raised to the higher level, suggesting that RJ increased glycolysis rate in cancer cells and amount of ATP probably needed for apoptosis and MRP-2 activity. Slight cytotoxic effect in cancer cells, induced by the treatment, could be due to oxidative stress provoked probably by polyphenols present in RJ. Our data indicate that the expression of apoptosis and biotransformation genes was changed in cells by treatment. Biotransformation of xenobiotics by CYPs and GSTP1 enzymes plays immense role in anticancer therapy, thus suppressing of these genes by RJ treatment could be very desirable. Namely, potential application of RJ with appropriate cytostatics could provide better anticancer effect. Although the significant cell selective effects of RJ were observed, further studies are necessary to clarify molecular mechanisms of RJ activity, investigate ability of RJ to affect specific components in different signal pathways or estimate eventual specificities in royal jelly content originating from Serbia. Royal jelly originating from Serbia could be considered as potential source of abundant bioactive substances used in anticancer therapy of certain cancer types.

\section{Acknowledgments}

The Ministry of Education, Science and Technological Development of the Republic of Serbia (Project No. III41010) supported this work. 


\section{References:}

[1] AuClair, C., Voisin, E. (1985): Nitroblue tetrazolium reduction. In: Greenwald, R.A. (ed.) Handbook of methods for oxygen radical research, CRC Press, Boka Raton.

[2] Baig, S., Seevasant, I., Mohamad, J., Mukheem, A., Huri, H.Z., Kamarul, T. (2016): Potential of apoptotic pathway-targeted cancer therapeutic research: Where do we stand? Cell Death \& Disease 7 (1): e2058. doi: 10.1038/cddis.2015.275

[3] BASkić, D., Popović, S., Ristić, P., ARseniJević, N. (2006): Analysis of cycloheximide-induced apoptosis in human leukocytes: Fluorescence microscopy using annexin V/propidium iodide versus acridine orange/ethidium bromide. Cell Biology International 30 (11): 924-932. doi: 10.1016/j.cellbi.2006.06.016

[4] Bustin, S.A. (2000): Absolute quantification of mRNA using real-time reverse transcription polymerase chain reaction assays. Journal of Molecular Endocrinology 25: 169-193. doi: 10.1677/jme.0.0250169

[5] Chan, F.K., Moriwaki, K., De Rosa, M.J. (2013): Detection of necrosis by release of lactate dehydrogenase (LDH) activity. Methods in Molecular Biology 979: 65-70. doi: 10.1007/978-1-62703-290-2_7

[6] Chen, K., Xu, X., Kobayashi, S., Timm, D., Jepperson, T., Liang, Q. (2011): Caloric Restriction Mimetic 2-Deoxyglucose Antagonizes Doxorubicin-induced Cardiomyocyte Death by Multiple Mechanisms. The Journal of Biological Chemistry 286 (25): 2199322006. doi: 10.1074/jbc.M111.225805

[7] Chomezynski, P., SACCHI, N. (1987): Single-step method of RNA isolation by acid guanidinium thiocyanate-phenol-chloroform extraction. Analytical Biochemistry 162 (1): 156-159. doi: 10.1006/abio.1987.9999

[8] Croom, E. (2012): Metabolism of xenobiotics of human environments. Progress in Molecular Biology and Translational Science 112: 31-88. doi: 10.1016/B978-0-12415813-9.00003-9

[9] Ćurčić, M.G., Stanković, M.S., Mrkalić, E.M., Matović, Z.D., Banković, D.D., CvetKović, D.M., ĐAČIĆ, D.M., MARKOVIĆ, S.D. (2012): Antiproliferative and proapoptotic activities of methanolic extracts from Ligustrum vulgare L. as an individual treatment and in combination with palladium complex. International Journal of Molecular Science 13 (2): 2521-2534. doi: 10.3390/ijms 13022521

[10] ĆurČić, M., Stanković, M., Cvetković, D., Topuzović, M., Marković, S. (2014): Ligustrum vulgare L.: In vitro free radical scavenging activity and pro-oxidant properties in human colon cancer cell lines. Digest Journal of Nanomaterials and Biostructures 9 (4): 1689-1697.

[11] Elmore, S. (2007): Apoptosis: A Review of Programmed Cell Death. Toxicologic Pathology 35 (4): 495-516. doi: 10.1080/01926230701320337

[12] Filipič, B., Gradišnik, L., Rihar, K., Šooš, E., Pereyra, A., PotoKar, J. (2015): Impact of royal jelly and HuIFEN- $\alpha \mathrm{N} 3$ on proliferation, glutathione, and lipid peroxidation in human colorectal adenocarcinoma cells in vitro. Archives of Industrial Hygiene and Toxicology 66 (4): 269-274. doi: 10.1515/aiht-2015-66-2632

[13] Hrycay, E.G., BANDIERA, S.M. (2015): Involvement of Cytochrome P450 in Reactive Oxygen Species Formation and Cancer. Advances in Pharmacology 74: 35-84. 
[14] Izuta, H., Chikaraishi, Y., Shimazawa, M., Mishima, S., Hara, H. (2009): 10Hydroxy-2-decenoic acid, a major fatty acid from royal jelly, inhibits VEGF-induced angiogenesis in human umbilical vein endothelial cells. eCAM 6 (4): 489-494.

[15] Kamogashira, T., Fujimoto, C., Yamasoba, T. (2015): Reactive Oxygen Species, Apoptosis, and Mitochondrial Dysfunction in Hearing Loss. Biomed Research International 2015: 1-7. doi: 10.1155/2015/617207

[16] Karadeniz, A., Simsek, N., Karakus, E., Yildirim, S., Kara, A., Can, I., Kisa, F., EMrE, H., TURKeli, M. (2011): Royal Jelly Modulates Oxidative Stress and Apoptosis in Liver and Kidneys of Rats Treated with Cisplatin. Hindawi Publishing Corporation Oxidative Medicine and Cellular Longevity 2011: 1-10. doi: 10.1155/2011/981793

[17] Kaur, M., Agarwal, C., Agarwal, R. (2009): Anticancer and Cancer Chemopreventive Potential of Grape Seed Extract and Other Grape-Based Products. The Journal of Nutrition 139: 1806S-1812S. doi: 10.3945/jn.109.106864

[18] LeE, D.J., Kang, S.W. (2013): Reactive Oxygen Species and Tumor Metastasis. Molecules and Cells 35 (2): 93-98. doi: 10.1007/s10059-013-0034-9

[19] Miao, P., Sheng, S., Sun, X., Liu, J., Huang, G. (2013): Lactate Dehydrogenase A in Cancer: A Promising Target for Diagnosis and Therapy. International Union of Biochemistry and Molecular Biology 65 (11): 904-910. doi: 10.1002/iub.1216

[20] Mofid, B., Rezaeizadeh, H., Termos, A., Rakhsha, A., Mafi, AR., TAheripanah, T., ARdakani, M.M., Taghavi, S.M.E., MoravVEJI, S.A., Kashi, A.S.Y. (2016): Effect of Processed Honey and Royal Jelly on Cancer-Related Fatigue: A Double-Blind Randomized Clinical Trial. Electronic Physician 8(6): 2475-2482.

[21] Mosmann, T. (1983): Rapid colorimetric assay for cellular growth and survival: application to proliferation and cytotoxicity assays. Journal of Immunology Methods $\mathbf{6 5}$ (1-2): 55-63.

[22] Nabas, Z., Haddadin, M.S.Y., Haddadin, J., NAZER, I.K. (2014): Chemical composition of royal jelly and effects of symbiotic with two different locally isolated probiotic strains on antioxidant activities. Polish Journal of Food and Nutrition Sciences 64 (3): 171-180. doi: 10.2478/pjfns-2013-0015

[23] Nakajima, Y., Tsuruma, K., Shimazawa, M., Mishima, S., Hara, H. (2009): Comparison of bee products based on assays of antioxidant capacities. BMC Complementary and Alternative Medicine 9: 1-9. doi: 10.1186/1472-6882-9-4

[24] Nasrallah, A., El-Sibai, M. (2014): Colorectal Cancer Causes and Treatments: A Minireview. The Open Colorectal Cancer Journal 7: 1-4. doi: $10.2174 / 1876820201407010001$

[25] Nissar, S., SAmeer, A.S., Rasool, R., Chowdri, N.A., RASHID, F. (2017): Glutathione S Transferases: Biochemistry, Polymorphism and Role in Colorectal Carcinogenesis. Journal of Carcinogenesis \& Mutagenesis 8: 1-9. doi: 10.4172/2157-2518.1000287

[26] ORŠOLIĆ, N. (2013): Royal jelly: component, efficiency, analysis and standardisation. Arhives of Industrial Hygiene and Toxicology 64 (3): 445-461.

[27] Pages, M.P., Outschoorn, U.E.M., Sotgia, F., Lisanti, M.P. (2015): Metastasis and Oxidative Stress: Are Antioxidants a Metabolic Driver of Progression? Cell Metabolism 22(6): 956-958. doi: 10.1016/j.cmet.2015.11.008 
[28] Pajaud, J., Kumar, S., Rauch, C., Morel, C., Aninat, C. (2012): Regulation of Signal Transduction by Glutathione Transferases. International Journal of Hepatology 2012: 111. doi: $10.1155 / 2012 / 137676$

[29] Pasupuleti, V.R., SAmmugam, L., RAmesh, N., Gan, S.H. (2017): Honey, propolis and royal jelly: a comprehensive review of their biological actions and health benefits. Oxidative Medicine and Cellular Longevity 2017: 1-21. doi: 10.1155/2017/1259510

[30] Pavel, C.I, Marghitas, L.A., Bobis, O., Desmirean, D.S., Sapcaliu, A., Radoi, I., MAdAs, M.N. (2011): Biological Activities of Royal Jelly - Review. Scientific Papers: Animal Science and Biotechnologies 44 (2): 108-118.

[31] Ramadan, M.F., Al-Ghamdi, A. (2012): Bioactive compounds and health-promoting properties of royal jelly: A review. Journal of Functional Foods 4: 39-52.

[32] Schmittgen, T.D., LiVAK, K.J. (2008): Analyzing real-time PCR data by the comparative $C_{t}$ method. Nature Protocols 3 (6): 1101-1108. doi: 10.1038/nprot.2008.73

[33] Shirzad, M., Kordyazdi, R., Shahinfard, N., Nikokar, M. (2013): Does Royal jelly affect tumor cells? Journal of HerbMed Pharmacology 2 (2): 45-48.

[34] Sodani, K., Patel, A., Kathawala, R.J., Chen, Z.S. (2012): Multidrug resistance associated proteins in multidrug resistance. Chinese Journal of Cancer 31 (2): 58-72.

[35] SugiYama, T., TAKahashi, K., Mori, H. (2012): Royal Jelly Acid, 10-Hydroxy-trans-2Decenoic Acid, as a Modulator of the Innate Immune Responses. Endocrine, Metabolic \& Immune Disorders - Drug Targets 12: 368-376.

[36] Supabphol, R., Supabphol, A. (2013): Cytoprotective potential of royal jelly on human umbilical vein endothelial cells against nicotine toxicity via catalase. European Journal of Medicinal Plants 3 (1): 88-98.

[37] Suzuki, K.M., Isohama, Y., Maruyama, H., Yamada, Y., Narita, Y., Ohta, S., ArAKI, Y., MiYATA, T., MishimA, S. (2008): Estrogenic Activities of Fatty Acids and a Sterol Isolated from Royal Jelly. eCAM. 5 (3): 295-302. doi: 10.1093/ecam/nem036

[38] Tamasi, V., Monostory, K., Prough, R.A., Falus, A. (2011): Role of xenobiotic metabolism in cancer: involvement of transcriptional and miRNA regulation of P450s. Cellular and Molecular Life Sciences 68 (7): 1131-46. doi: 10.1007/s00018-010-0600-7

[39] Torres-Acosta, M.A., Aguilar-Yanez, J.M., Rito-Palomares, M., TitchenerHoOKER, N.J. (2015): Economic Analysis of Royalactin Production Under Uncertainty: Evaluating the Effect of Parameter Optimization. Biotechnology Progress 31: 744-749.

[40] Valvona, C.J., Fillmore, H.L., Nunn, P.B., Pilkington, G.J. (2016): The Regulation and Function of Lactate Dehydrogenase A: Therapeutic Potential in Brain Tumor. Brain Pathology 26 (1): 3-17. doi: 10.1111/bpa.12299

[41] Zhai, W., Jeong, H., Cui, L., Kraine, D., Tuian, R. (2005): In vitro analysis of huntingtin-mediated transcriptional repression reveals multiple transcription factor targets. Cell 123 (7): 1241-1253. doi: 10.1016/j.cell.2005.10.030

[42] Zhou, Y., Zheng, J., Li, Y., Xu, D.P., Li, S., Chen, Y.M., Li, H.B. (2016): Natural Polyphenols for Prevention and Treatment of Cancer. Nutrients 8 (515): 1-35.

[43] Žižić, J.B., Vuković, N.L., Jadranin, M.B., AnĐElković, B.D., TeŠEvić, V.V., KaCANiova, M.M., SukdolaK, S.B., Marković, D.S. (2013): Chemical composition, cytotoxic and antioxidative activities of ethanolic extracts of propolis on HCT-116 cell line. Journal of the Science of Food and Agriculture 93: 1-9. doi: 10.1002/jsfa.6132/full 